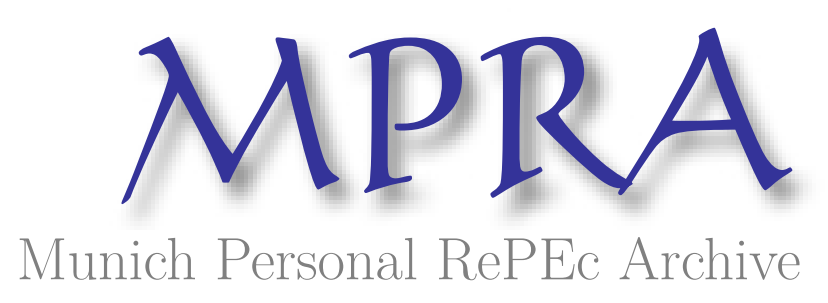

\title{
Liquidity and its determinants
}

Basir, Yana

20 May 2018

Online at https://mpra.ub.uni-muenchen.de/86863/

MPRA Paper No. 86863, posted 21 May 2018 09:15 UTC 


\title{
Journal of
}

\section{Bajaj Auto}

\section{"Liquidity and its determinant"}

\author{
Prepare by: \\ Nur Liyana Mohd Basir \\ Universiti Utara Malaysia
}




\title{
ACKNOWLEDEMENTS
}

This study was prepared for the partial fulfilment of BWRR3123 Corporate Governance.

Frequent people who have gave support and helping in finishing my study, I would like to thank and grateful especially to my parents, friends who always helping me in giving moral support and using their own facilities.

In this special occasion, I would love to thank to my only lecturer of Corporate Governance, Dr Waeibrorheem Waemustafa for his advice, guidance, the energy of teaching us SPSS again and again on helping us to complete my study.

\begin{abstract}
Liquidity risk management is really important in any organization to manage their liquidity. This study attempted to investigate the relationship between firm-specific and macroeconomic factors toward liquidity risk in Bajaj Auto company. This study is based on annual report of 5 years, the duration starting 2011-2015. The analysis show that firm specific factors and macroeconomic factors influence liquidity risk.
\end{abstract}

Keywords: Liquidity risk, Corporate governance, Firm-specific factors, Macroeconomic factors 


\section{TABLE OF CONTENTS}

\section{Content}

Page

Acknowledgment 2

Abstracts 2

Table of Contents 3

List of Tables

CHAPTER 1: INTRODUCTION 5

1.1 Introduction 5

1.2 Overview of Bikes and Bikers 5

$\begin{array}{lr}1.3 \text { Problem Statements } & 6\end{array}$

$\begin{array}{ll}1.4 \text { Research Objectives } & 7\end{array}$

$\begin{array}{ll}1.5 \text { Research Questions } & 7\end{array}$

$\begin{array}{ll}\text { 1.6 Scope of Study } & 7\end{array}$

$\begin{array}{ll}\text { 1.7 Organisation of the Study } & 7\end{array}$

CHAPTER 2: LITERATURE REVIEW 9

2.1 Introduction 9

2.2 Profitability 9

$\begin{array}{ll}2.3 \text { Corporate Governance } & 10\end{array}$

$\begin{array}{ll}2.4 \text { Financial Risk } & 10\end{array}$

$\begin{array}{ll}2.5 \text { Liquidity Risk } & 11\end{array}$

CHAPTER 3: METHODOLOGY 12

3.1 Introduction 12

3.2 Data Source 12

3.3 Research Approach $\quad 13$

3.4 Sampling Unit 13

3.5 Data Completion Analysis 13

3.6 Statistical Package for Social Science (SPSS) 14 
CHAPTER FOUR: FINDINGS AND ANALYSIS

$\begin{array}{ll}4.1 \text { Introduction } & 15\end{array}$

4.2 Profitability 15

4.3 Corporate Governance 16

4.4 Liquidity Risk 17

$\begin{array}{ll}4.5 \text { Correlation } & 17\end{array}$

$\begin{array}{ll}4.6 \text { Coefficient } & 19\end{array}$

$\begin{array}{ll}\text { 4.7 Model Summary } & 20\end{array}$

CHAPTER FIVE: DISCUSSION AND CONCLUSION 22

5.1 Introduction 22

5.2 Limitations 23

$\begin{array}{ll}5.3 \text { Recommendations } & 24\end{array}$

$\begin{array}{lr}\text { REFERENCES } & 24\end{array}$ 


\section{CHAPTER ONE}

\section{INTRODUCTION}

\subsection{Introduction}

Bajaj Auto Limited is India's biggest maker of bikes and bikes. The organization for the most part has fall over behind its Japanese adversaries in innovation yet has contributed intensely to get up to speed. Its solid suit is high-volume creation; it is the most reduced cost bike producer on the planet. Although freely claimed, the organization has been controlled by the Bajaj family since its establishing. Bajaj Auto create and offers cruisers, bikes and auto rickshaws. Bajaj Auto is a piece of the Bajaj Group. It was established by Jamnalal Bajaj in Rajasthan in the 1940s. It is situated in Pune, Mumbai, with plants in Chakan, Waluj (close Aurangabad) and Pantnagar in Uttarakhand. They managed to sell 100,000 vehicles in 1977. The most seasoned plant at Akurdi (Pune) now houses the R\&D focus 'Ahead'. Bajaj Auto is the world's 6th biggest producer of cruisers and the second-biggest in India.It is the world's biggest three-wheeler maker.

\subsection{Overview of Bikes and Bikers}

These company manufacture two-wheelers and three wheelers and obtained the license from the Government of India. In India, Bajaj Auto has a conveyance system of 485 merchants and more than 1,600 approved administrations focuses. It has 171 elite merchants for the threewheeler section.It has add up to 3750 provincial outlets in rustic territories. The Bajaj mark is well- known over a few nations in Latin America, Africa, Middle East, South and South East Asia. It has a dissemination organize in 50 nations with a predominant nearness in Sri Lanka, Colombia, Bangladesh, Mexico, Central America, Peru and Egypt. It has specialized tie up with Kawasaki Heavy Industries of Japan to make most recent models in the two- wheeler 
space. Bajaj Auto has propelled brands like Boxer, Caliber, Wind125, Pulsar and some more. It has additionally propelled India's first genuine cruiser bicycle, Kawasaki Bajaj Eliminator.

The Bajaj Group was invented in the main days of India's freedom from Britain. Its author, Jamnalal Bajaj, had been an adherent of Mahatma Gandhi, who purportedly introduced to him as a fifth child. 'At whatever point I talked about well-off men turning into the trustees of their riches for the benefit of all I generally had this dealer sovereign mainly at the top of the priority list,' said the Mahatma after Jamnalal's demise. Through their company journey to succeed, in 2005 Bajaj CT 100 bagged Motorcycle Total Customer Satifaction by TNS Automotive. On 2006, Bajaj Auto awarded Super Platinum Award for Manufacturing Excellence by Frost and Sullivan. Bajaj Platina 100 cc won bike by NDTV Profit Bike India. On 2007, they have been rewarded TV18 Autocar Auto Awards by CNBC. Bajaj Auto awarded NDTV Profit Business Leadership Award 2010 on $1^{\text {st }}$ September 2010 by Hon'ble Finance Minister Shri Pranab Mukherjee. In 2015 Bajaj Auto has presented the all-new Platina electric begin 100 cc bicycle to the long-distance commuter.

\subsection{Problem Statement}

Firms need to manage their liquidity risk efficiently in order to make a profit and prevent huge loss. Independent variables such as firm and macro variables can influence the performance of liquidity risk. By identifying the factors that underwrite towards liquidity risk, immediate action should be taken 


\subsection{Research Objectives}

This study aims to determine the firm's liquidity risk and independent variables in company. Objectives of this study are:

1. To examine the firm-specific factors and macroeconomic factors towards liquidity risk.

2. To examine the relationship between firm-specific factors and liquidity risk.

3. To examine the relationship between macroeconomic factors and liquidity risk.

\subsection{Research Questions}

1. Is there any relationship between firm-specific and macroeconomic factors towards liquidity risk?

2. Is there any relationship between firm-specific factors and liquidity risk?

3. Is there any relationship between macroeconomic factors and liquidity risk?

\subsection{Scope of Study}

The sample of study consists of manufacturing company from India, Bajaj Auto. The accounting, financial ratios and annual report was based on 5 years performance from 20112015.

\subsection{Organization of the Study}

This study includes of five main chapter. Chapter one is telling about the introduction of the company, which consists overview of study, problem statement, research objectives, research questions, scope of study and organization of the study. Chapter two brief about 
literature reviews, discussed about firm's liquidity and independent variables. Chapter three explain the theoretical framework, measurement of variables, research methodology and data analysis. Chapter four discuss the result of findings on this data using SPSS, diagnostic test, correlation. Chapter five explain the summary and the conclusion of the study. 


\section{CHAPTER TWO}

\section{LITERATURE REVIEW}

\subsection{Introduction}

Mobility, especially in terms of transportation defines success of a nation or a community. The rich people usually being driven and have their own car and the poor people which is a lower standard of netizen only depend on carts pulled by bullocks and horse carriages. The existence of bicycle helps this poor people to make things easy and reducing their time. The early bike that has been presented in India was invented on 19950, Indian starts imagination about bikes and made their two wheelers on 1950. Then for 19954, Indian Govt well-organized 800 bikes for men on Pakistan's border. The government of Independent India laid tough restrictions on the imported motorcycle industry by encouraging manufacturing and assembly in the country. The government incentivised local manufacturers to collaborate with international brands to bring high quality two wheelers to the Indian masses, it also controlled the number of two wheelers brands would produce as well as the number of licenses awarded to manufacture and assemble (Venkatesh.S, 2017).

\subsection{Profitability}

Bajaj Auto is the second biggest biker producer in India and top three in the world, has a scope of items - from the $100 \mathrm{cc}$ Platina to the $373 \mathrm{cc}$ Dominar. It offers other higher controlled bicycles through its organization with Austrian bicycle creator KTM, in which wander it holds a 47 for every penny stake. Bajaj has a solid contender in the "simple riding/cruiser" segment that will develope in the markets over the world "We hope to bring to bear upon global markets the individual strengths of the partners, including brand position and perception, design and development technology, quality and cost competitiveness and worldwide distribution," the firms said. Bajaj Auto also its existing partnership with KTM, Europe's largest motorcycle maker, has $48 \%$ equity stake to be closing in Ducati brand which they going to sell it. Since Ducati brand is and international brand that everyone wants to 
collaborate with, but with Bajaj Auto it only last one month. According to Rajiv Bajaj, MD of Bajaj Auto hinted "We are very close to finalising a very promising alliance, it's not certain, that it will happen, but if it happens, it will open up enormous possibilities for the company. That is why we keep our money (cash on books) with us, so, once in a while, when an opportunity comes along, we are ready."

\subsection{Corporate Governance}

In this literature review part, it is really important to know the customer perception report on how they are putting a rate on this brand. This report consists of four keywords which is expectations, purchase decision, customer services and future purchases. Expectations means how company and customer needs can be meet. Usually customer will always stand for price and quality and it includes in expectation of customer. Second, purchase decision is giving an opportunity for the company why the customer choose their product and rating question based on their experience. For the next product they will know what the strength is and what should they add to satisfy the needs of their customer. Customer services is to get know what problem is that customer is facing. It is one of the most important step what company can have. For this report the customer will rate a company in three key which are timeliness, customer service and expertise.

\subsection{Financial risk}

Financial risk is the likelihood that investors will lose cash when they put resources into an organization that has debt. At the point when an organization uses debt financing, its banks are reimbursed before its investors if the organization winds up bankrupt. There are a few types of financial risk which are credit risk, liquidity risk, foreign investment risk, asset backed risk, currency risk and equity risk. The higher the capital structure of a firm, the more obligation the 
firm has a tendency to have. The higher the capital structure, the more financial risk the firm tends to endure. The capital structure can affect the asset prices and financial risk can affect business risk. In the illiquidity regime, intermediaries are close with their capital or collateral constraints and there is “cash-in-the-market" pricing (Allen and Gale, 1994,1998).

\subsection{Liquidity ratio}

Liquidity risk is the hazard that an organization or bank might be not able meet short term budgetary request. This more often than not happens because of the powerlessness to change over a security or hard asset for money without lost capital as well as salary all the while. Nikolaou stated that three primary liquidity thoughts, namely central bank liquidity, market liquidity and funding liquidity are characterized. Their dynamic linkages can give us a decent understanding of the liquidity workings in the money related framework and uncover positive or negative impacts for financial stability (2009). 


\section{METHODOLOGY}

\subsection{Introduction}

Research methodology is the procedure used to gather data and information to do business decisions. The philosophy may incorporate production investigate, interviews, overviews and other research procedures, and could incorporate both present and chronicled data. It is known as the most essential advance in promoting research process is to define the issue. Decide for the investigation because the problem we know is half solved. That was the reason that at most care was taken while characterizing several parameters of the issue. In the wake of giving through meeting to generate new ideas, targets were selected and the set on the base of these destinations. A questionnaire was outlined significant emphasis of which was assembling new thoughts or understanding in order to decide and tie out solution to the issues. The study is based on descriptive research and explanatory building from secondary data from sources of reference. Exploratory research means research conducted for a problem that has been solved and not clear to improve final research design. Exploratory research helps to find out the best research design, data collection which is came from questionnaire and secondary data, and selection of subjects. From this exploratory, we can know the projects of Bajaj Auto Ltd through informal interviews with management staffs and workers. The results of case company can be used to explain empirical patterns.

\subsection{Data Source}

Research included primary data and secondary data. Primary data is information that you gather particularly to the purpose of research project. Benefit of this primary data that it can suits with our research needs and it is expensive to be obtain. Secondary data is data that 
was collected by someone other than owner and this data was collected for the purpose of research project and it is easy to be obtain.

\subsection{Research Approach}

The research approach was utilized overview technique which is a generally utilized method for data collection and most appropriate for descriptive type of research consists of research instrument like survey which can be organized and unstructured. Target population is very much identified and a few methods like personal and telephone interviews are employed in Bajaj Auto Ltd.

\subsection{Sampling Unit}

Target of people who going to be sample of this research project. Usually the sample could be the employee and employer of Bajaj Auto Ltd.

\subsection{Data Completion and Analysis}

After data has been collected, the analysis and interpretation will be presented to make a certain conclusion based on the findings of the project. In this data, there have independent variables and dependent variables that can influence the data analysis. Which is dependent variables(DV) is firm's liquidity risk, independent variables(IV) are firm specific factors and macroeconomic factors. 


\subsection{Statistical Package For Social Science}

In this study, IBM SPSS Statistic 25 have been used to generate the data. This SPSS helps a lot on gaining result and make immediate conclusion of company performance in this five years which is $2011,2012,2013,2014$ and 2015. SPSS Statistics is a software packaged that utilized for statistical analysis. Since quite a while ago delivered by SPSS Inc., it was obtained by IBM in 2009. The present variants are named IBM SPSS Statistics. 


\section{CHAPTER FOUR}

\section{FINDINGS AND ANALYSIS}

\subsection{Introduction}

Financial statement analysis is the way toward inspecting and assessing an organization's monetary statements, (for example, the asset report or benefit and loss), in this way picking up a comprehension of the financial of the organization and empowering more compelling basic leadership.Financial statement record the data but this information must be assessed through financial statement analysis to wind up more helpful to investors, shareholders and other invested individuals.

\subsection{Profitability}

Figure 4.2 Average return on asset for each year

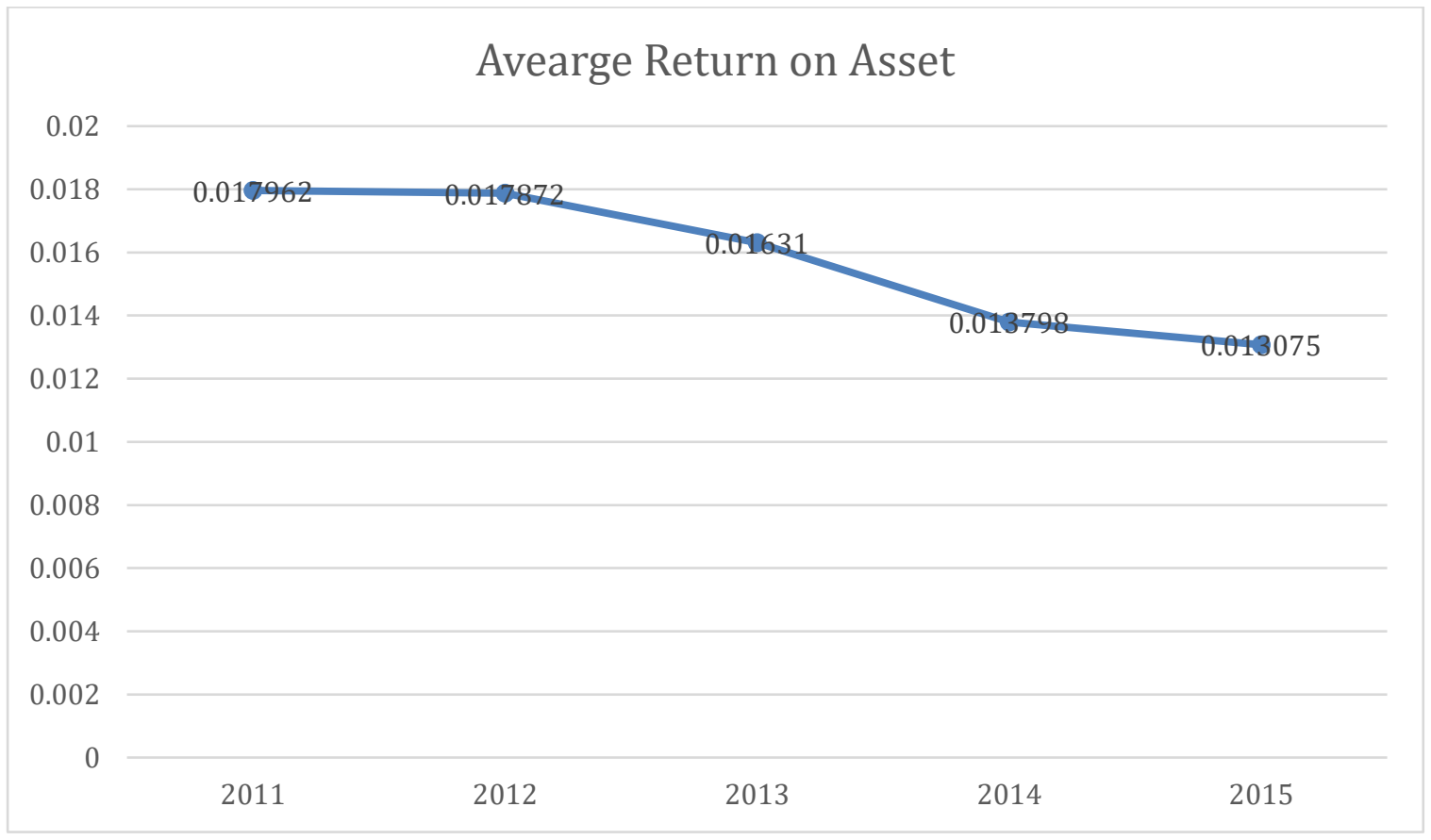


The figure above shows that the average return on asset (ROA) was shown in 5 years performance of Bajaj Auto company. As we can see, the performance was good at first 2 years and sink on 2013, 2014 and 2015. This average return on asset (ROA) is a measurement of how gainful an organization is in respect to its aggregate resources. ROA gives a manager, investors, or shareholder a thought in the matter of how effective an organization's administration is at utilizing its resources for create income. On 2011, the average was $0.0179 \%$ and 2012 was a little bit down $0.0178 \%$, we can see the company is efficient in utilizing their assets to generate income. Furthermore, the average on 2011 was the highest value among this 5 years performance.

\subsection{Corporate governance}

\subsection{Average index score for each company}

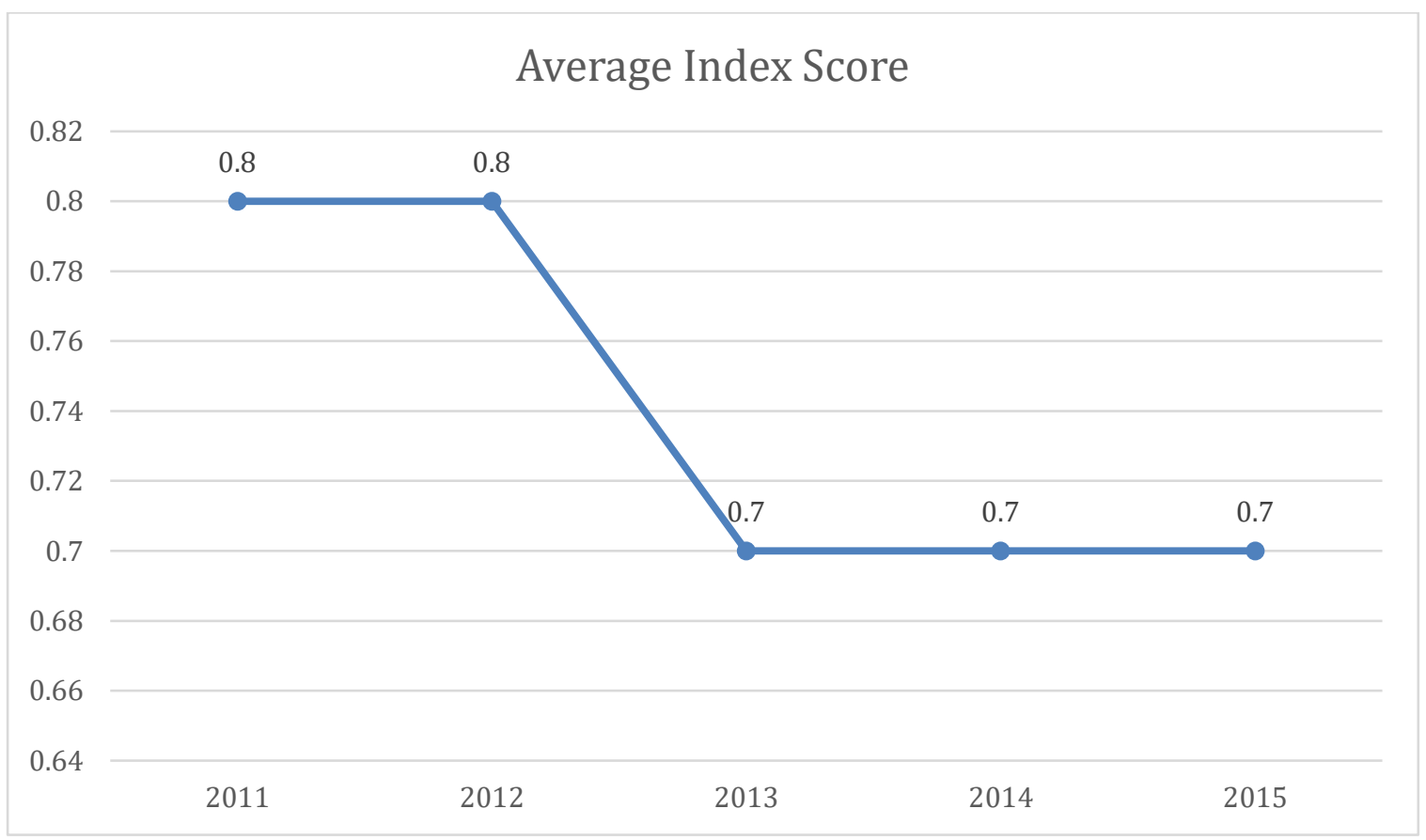

Average index score is a measure of changes in a manager gathering of individual information efforts, or at the end of the day, a multiple measure that totals 
various indicators. This average is a measurement to see the level of compliance of this company in 5 years, whether they are using the principle of corporate governance. Based on this line chart, we can see the index score was a bit drown when it comes to year 2013, 2014 and 2015. On getting a better performance, corporate governance is really important. Whether they implement four codes of corporate governance which are transparency, fairness, accountability and independent. Besides, this index score can affect the profit of the company. We can see on figure 4.2 average return on asset was sink on 2013, 2014 and 2015, and was affected by corporate of governance. On 2011 and 2012, the index score was 0.8, followed by 2013, 2014 and 2015 was drown to 0.7 .

\subsection{Liquidity risk}

\subsection{Average current ratio for each company}

\section{Average Current Ratio}

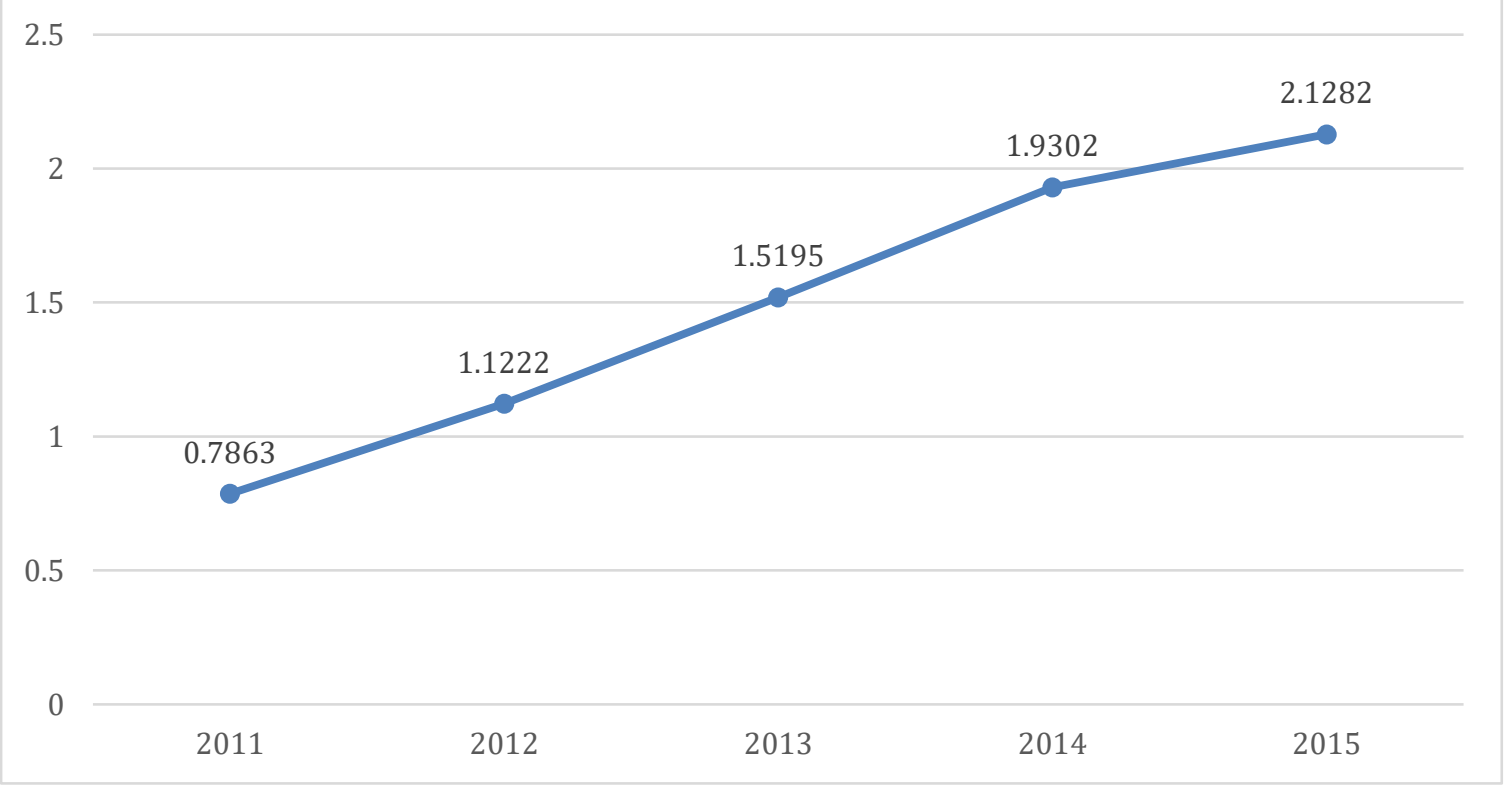


Liquidity risk is the risk that stems from the absence of attractiveness of an assumption that can't be purchased or sold rapidly enough to predict or limit a loss. Which means, risk that a company may be powerless to meet short term financial demands. This usually occurs due to the incapability to change a hard asset to cash without a loss of capital. It is measured that on 2015 was the highest current ratio, 2.1282. They have enough current assets to cover their current liabilities. On 2011, it was the lowest current ratio, 0.7863 which means they don't have enough asset to cover for current liabilities. Starting 2012, the current ratio was getting good in terms of covering current liabilities because the value is getting higher from year to year.

\section{Table 4.6 Correlations}

\begin{tabular}{|c|c|c|c|c|c|c|c|c|c|}
\hline \multicolumn{10}{|c|}{ Correlations } \\
\hline & & $\begin{array}{l}\text { CURRENT } \\
\text { RATIO }\end{array}$ & ROA & ROE & $\begin{array}{l}\text { AVERAGE } \\
\text { COLLECTION } \\
\text { PERIOD }\end{array}$ & $\begin{array}{l}\text { DEBT TO } \\
\text { INCOME }\end{array}$ & $\begin{array}{l}\text { OPERATIONA } \\
\text { LINCOME }\end{array}$ & $\begin{array}{l}\text { OPERATIONA } \\
\text { L MARGIN }\end{array}$ & STIDV \\
\hline \multirow[t]{8}{*}{ Pearson Correlation } & CURRENT RATIO & 1.000 & -.969 & -.986 & .836 & .959 & -.850 & -.366 & .572 \\
\hline & ROA & -.969 & 1.000 & .981 & -.796 & -.998 & .775 & .202 & -.449 \\
\hline & ROE & -.986 & .981 & 1.000 & -.877 & -.968 & .876 & .209 & -.533 \\
\hline & $\begin{array}{l}\text { AVERAGE COLLECTION } \\
\text { PERIOD }\end{array}$ & .836 & -.796 & -.877 & 1.000 & .754 & -.983 & -.089 & .332 \\
\hline & DEBT TO INCOME & .959 & -.998 & -.968 & .754 & 1.000 & -.733 & -.205 & .449 \\
\hline & OPERATIONAL INCOME & -.850 & .775 & .876 & -.983 & -.733 & 1.000 & .160 & -.483 \\
\hline & OPERATIONAL MARGIN & -.366 & .202 & .209 & -.089 & -.205 & .160 & 1.000 & -.282 \\
\hline & STIDV & .572 & -.449 & -.533 & .332 & .449 & -.483 & -.282 & 1.000 \\
\hline
\end{tabular}

Pearson correlation is to measure the strength between two variables, which is dependent variable (liquidity risk), and independent variables (firm-specific variables and macroeconomic variables).

Table 4.7 Table of correlation benchmark 


\begin{tabular}{|l|l|}
\hline Size of correlation & Interpretation \\
\hline 0.90 to $1.00(-0.90$ to -1.0$)$ & Very high positive (negative) correlation \\
\hline 0.70 to $0.90(-0.70$ to -0.90$)$ & High positive (negative) correlation \\
\hline 0.50 to $0.70(-0.50$ to -0.70$)$ & Moderate positive (negative) correlation \\
\hline 0.30 to $0.50(-0.30$ to -0.50$)$ & Low positive (negative) correlation \\
\hline 0.00 to $0.30(0.00$ to -0.30$)$ & Negligible correlation \\
\hline
\end{tabular}

Based on table 4.6 , the average collection period is 0.836 , high positive correlation and significantly correlated to liquidity risk. It shows that liquidity risk increase, the average collection period also increases. If the liquidity risk is high, the chance of assets turning to cash can be in a short period and fast. Meanwhile, the correlation return on asset is very negative correlation, -0.969 not significantly correlated to dependent variable. Besides, Beta is moderate positive correlation and not significantly correlated to liquidity risk with $p$-value $>0.10$. All of these independent variables are not significantly correlated to dependent variable.

\section{Table 4.8 Cofficients}

\begin{tabular}{|c|c|c|c|c|c|c|c|c|c|c|}
\hline \multicolumn{11}{|c|}{ Coefficients $^{a}$} \\
\hline \multirow[b]{2}{*}{ Model } & & \multicolumn{2}{|c|}{ Unstandardized Coefficients } & \multirow{2}{*}{$\begin{array}{c}\text { Standardized } \\
\text { Coefficients } \\
\text { Beta } \\
\end{array}$} & \multirow[b]{2}{*}{$t$} & \multirow[b]{2}{*}{ Sig. } & \multicolumn{2}{|c|}{$95.0 \%$ Confidence Interval for B } & \multicolumn{2}{|c|}{ Collinearity Statistics } \\
\hline & & $\mathrm{B}$ & Std. Error & & & & Lower Bound & Upper Bound & Tolerance & VIF \\
\hline \multirow[t]{2}{*}{1} & (Constant) & 3.686 & .218 & & 16.908 & .000 & 2.992 & 4.380 & & \\
\hline & ROE & -.825 & .080 & -.986 & -10.288 & .002 & -1.080 & -.570 & 1.000 & 1.000 \\
\hline \multirow[t]{3}{*}{2} & (Constant) & 4.353 & .102 & & 42.851 & .001 & 3.915 & 4.790 & & \\
\hline & ROE & -.796 & .019 & -.951 & -42.821 & .001 & -.876 & -.716 & .956 & 1.046 \\
\hline & OPERATIONAL MARGIN & -3.737 & .498 & -.167 & -7.510 & .017 & -5.878 & -1.596 & .956 & 1.046 \\
\hline
\end{tabular}

Based on table correlation benchmark, the independent variables that has connection with dependent variable can be determined through level of $p$-value. P-value $<0.01$ indicates 
that independent variable has the most influence on the dependent variable. Meanwhile, pvalue $<0.10$ has the lowest influence.

According to the table 4.8, the independent that only has a connection with dependent variable is return on equity and operational margin. Return on equity (ROE) is negative with, $\mathrm{t}=-42.821$. Meanwhile operational margin was found -7.510 , and found to be a negative but has a significant relationship with liquidity risk. It has the least significant influence rather than return on equity.

\section{Table 4.9 Model Summary}

\begin{tabular}{|c|c|c|c|c|c|}
\hline \multicolumn{6}{|c|}{ Model Summary ${ }^{c}$} \\
\hline Model & $\mathrm{R}$ & R Square & $\begin{array}{c}\text { Adjusted R } \\
\text { Square }\end{array}$ & $\begin{array}{l}\text { Std. Error of } \\
\text { the Estimate }\end{array}$ & $\begin{array}{l}\text { Durbin- } \\
\text { Watson }\end{array}$ \\
\hline 1 & $.986^{a}$ & .972 & .963 & .1064000 & \\
\hline 2 & $1.000^{b}$ & .999 & .998 & .0241156 & 2.056 \\
\hline
\end{tabular}
a. Predictors: (Constant), ROE
b. Predictors: (Constant), ROE, OPERATIONAL MARGIN
c. Dependent Variable: CURRENT RATIO

Table 5.0 ANOVA result 


\begin{tabular}{|c|c|c|c|c|c|c|}
\hline \multicolumn{7}{|c|}{ ANOVA $^{a}$} \\
\hline Model & & $\begin{array}{l}\text { Sum of } \\
\text { Squares }\end{array}$ & df & Mean Square & $\mathrm{F}$ & Sig. \\
\hline \multirow[t]{3}{*}{1} & Regression & 1.198 & 1 & 1.198 & 105.838 & $.002^{\mathrm{b}}$ \\
\hline & Residual & .034 & 3 & .011 & & \\
\hline & Total & 1.232 & 4 & & & \\
\hline \multirow[t]{3}{*}{2} & Regression & 1.231 & 2 & .615 & 1058.349 & $.001^{c}$ \\
\hline & Residual & .001 & 2 & .001 & & \\
\hline & Total & 1.232 & 4 & & & \\
\hline
\end{tabular}

a. Dependent Variable: CURRENT RATIO

b. Predictors: (Constant), ROE

c. Predictors: (Constant), ROE, OPERATIONAL MARGIN

According to Table 4.9 above, the adjusted R Square is equal to $96.3 \%$. This show that by using all internal and macro independent variables which known as Return on asset, Return on equity, Average collection period, Operational income, Operational margin, Beta and Debt to income shows that, the variables used in the model explains that $96.3 \%$ of the variance in the liquidity of Bajaj Auto company, manufacturing base in India. Meanwhile the remaining $3.7 \%$ of the adjusted R Square remain unknown, this tell us that $3.7 \%$ of the adjusted $\mathrm{R}$ Square is the variance of liquidity risk of the Bajaj Auto that unable to be explained by both internal and macro variables.

Besides, the ANOVA result table shows a significant value of 0.001 which is below value (p?0.05). It tells us that the variable is significantly represent the model. This value is acceptable that can specify the model of study.

\section{CHAPTER FIVE}




\section{DISCUSSION AND CONCLUSION}

\subsection{Introduction}

This study is aiming to regulate the firm's liquidity risk and its factors in Bajaj Auto company. To achieve this objective, firm-specific factors and macroeconomic factors were used in this study. In this final chapter, the argument will be based on research and finding analysis in chapter four.

\subsection{Discussion of result}

This study aims to determine the firm's liquidity risk and independent variables in company. Objectives of this study are:

1. To examine the firm-specific factors and macroeconomic factors towards liquidity risk.

2. To examine the relationship between firm-specific factors and liquidity risk.

3. To examine the relationship between macroeconomic factors and liquidity risk.

Based on the table of correlation (Table 4.6) and coefficient (Table 4.8), there an evidence showing that independent variables affected dependent variable, liquidity risk. The coefficient table show us that the independent variables that has connection with dependent variable can be determined through level of $\mathrm{p}$-value. $\mathrm{P}$-value $<0.01$ indicates that independent variable has the most influence on the dependent variable. Meanwhile, p-value $<0.10$ has the lowest influence.

According to the table 4.8, the independent that only has a connection with dependent variable is return on equity and operational margin. Return on equity (ROE) is negative with, 
$\mathrm{t}=-42.821$. Meanwhile operational margin was found -7.510 , and found to be a negative but has a significant relationship with liquidity risk. It has the least significant influence rather than return on equity.

For model summary, according to Table 4.9 above, the adjusted R Square is equal to 96.3\%. This show that by using all internal and macro independent variables which known as Return on asset, Return on equity, Average collection period, Operational income, Operational margin, Beta and Debt to income shows that, the variables used in the model explains that $96.3 \%$ of the variance in the liquidity of Bajaj Auto company, manufacturing base in India. Meanwhile the remaining 3.7\% of the adjusted R Square remain unknown, this tell us that $3.7 \%$ of the adjusted R Square is the variance of liquidity risk of the Bajaj Auto that unable to be explained by both internal and macro variables. Besides, the ANOVA result table shows a significant value of 0.001 which is below value (p?0.05). It tells us that the variable is significantly represent the model. This value is acceptable that can specify the model of study.

\subsection{Limitations}

This study is only about manufacturing industry in India. It also limited to 5 years duration starting 2011-2015. The study is only based on financial report of Bajaj Auto company every year. Thus, only limited amount of sources and information can be found due to the time constraint.

\subsection{Recommendations}


Based on the findings, the firm-specific and macroeconomic factors has a significant relationship with dependent variable, liquidity risk. The corporate governance is really important for any company to perform better in their future result. We can see through findings, the index score can have affected company performance in terms of how many meetings are their board of members attempt, did the fairness happen in their company. This kind of action can help company to perform better. On getting a better performance, corporate governance is really important. Whether they implement four codes of corporate governance which are transparency, fairness, accountability and independent.

\section{REFERENCES}

BAJAJ AUTO-Expansion and Diversification :. (1995, November 04). Retrieved from http://www.epw.in/journal/1995/44/companies-uncategorised/bajaj-auto-expansion-anddiversification.html

6 Examples of Liquidity Risk. (n.d.). Retrieved from https://simplicable.com/new/liquidity-risk

Global. (n.d.). Retrieved from https://www.globalbajaj.com/global/english/aboutus/about-bajaj/history/

$$
\text { India GDP | 1960-2018 | Data | Chart | Calendar | Forecast | News. (n.d.). Retrieved }
$$
from https://tradingeconomics.com/india/gdp

India Unemployment Rate | 1983-2018 | Data | Chart | Calendar | Forecast. (n.d.). Retrieved from https://tradingeconomics.com/india/unemployment-rate

(n.d.). Retrieved from

https://www.bajajauto.com/bhil/profile/profile_rahulbajaj.html 
Staff, I. (2018, March 23). Financial Statement Analysis. Retrieved from https://www.investopedia.com/terms/f/financial-statement-analysis.asp

Two Wheeler Industry in India - Introduction \& History. (2017, June 12). Retrieved from http://www.spareaze.com/two-wheeler-industry-india/

Venkatesh, S. (2017, May 09). History of Bikes in India - Drivojoy Diaries. Retrieved from https://blog.drivojoy.com/history-of-bikes-in-india-99d50f060bd 